\title{
Land Suitability Assessmemt in Continental Grits of Northwestern Nigeria for Rainfed Crop Production
}

\section{G. A. Oluwatosin}

Institute of Agricultural Research and Training, Obafemi Awolowo University, P. M. B. 5029, Ibadan, Nigeria. E-mail: gaboluwatosin@yahoo.com

\begin{abstract}
The suitability of soils on continental grits in northwestern part of Nigeria was assessed for selected land use types (LUTs), using a qualitative physical land evaluation methodology. The results indicated that the soils of the landscape were currently not suitable (N1,10-18) for cereals but marginally suitable (S3, 47-56) for grain legumes. Potentially, all the evaluating units were moderately suitable(S2, 61-69) for cereals. Soils on upland and valley bottom were moderately suitable $(S 2,66-76)$, while those on plain were highly suitable (S1.82-88) for grain legumes. Soils on plains were potentially more suitable for the crop considered than the soils on the upland and valley bottom. The major limitations were nutrient availability (f) which cut across the landscape, erosion (inter-rill) hazard (e) at the upland and oxygen availability (o) at the plains and valley bottom. However, nutrient availability was more important consideration because land users (farmers) who crop the land manage the soils with little or no soil fertility management system despite the very low nutrient status of the soils. The landscape will only be suitable for both cereals and grain legumes with the use of high fertility management practices. Subsequent comprehensive quantitative evaluation methods using computer models to simulate soil-water flow and crop growth can then be focused on potentially suited land.
\end{abstract}

\section{Introduction}

Land evaluation is the processes of assessing the possible uses of land for agriculture, engineering, forestry, recreation, industry and conservation. In the agricultural context, it is the assessment for a specific kind of land utilization, e.g. extensive grazing, rainfed farming, irrigation and agriculture. Land evaluation methods aim at assessing land qualities or suitability for specific landuse, as conditioned by biophysical parameters (Beek, 1978; Smit et al., 1984). The physical resources remain reasonably stable, unlike the socio-economic resources that are affected by social, economic and political setting (Dent \& Young, 1981). Van Ranst et al.(1996) suggested that derivation of physical land suitability is a prime requisite for land-use planning and development, since it guides decisions on land utilization type
(LUT) for optimal use of the land resources.

There are several approaches to land evaluation for which Van Lanen (1991) identified three general types. The first one is qualitative evaluation based mainly on expertjudgement, where physical suitability is obtained by qualitative procedure. This approach gives useful result that generalizes the constraint of an area for specified kind of land use type. The FAO (1976) is an example. The approach is presented in discretely ranked classes (e.g. S1, S2, S3, $\mathrm{N} 1$ and N2). The FAO concept is mostly commonly applied, and, although it is a qualitative approach, it can be complemented and enhanced by more quantitative methods (Yizengaw \& Veheye, 1995).

The second type includes a qualitative evaluation based on parametric methods that assess the suitability of land on a 
continuous scale, instead of discrete classes. The essentials of these methods are expressed by a mathematical model which is either multiplicative (e.g. $P=A^{*} E^{*} C^{*} n$ ) or additive ( e.g. $P=A+B+C+n$ ), where $P$ is the parametric score, and $\mathrm{A}, \mathrm{B}, \mathrm{C}$ and $\mathrm{n}$ are ratings of land qualities. In these approaches, the best land receives the maximum score (e.g. 1), while the poorest receives lower scores (e.g. 0 ). An example of these approaches is the Storie index rating (SIR), which is a multiplicative procedure (Storie, 1933). The most limiting factor is used to determine land suitability so that the most limiting land quality dictates the overall suitability (Sys et al., 1991; Van Diepen et al., 1991). The third method is based on process-orientated simulation models where land performance is related to individual land characteristics with their net effect assessed using a model of land function. These quantified methods usually require high data input, which make them more expensive.

Of all the different approaches to land evaluation, each has different data needs and different qualities of prediction. There are no rules that indicate when any given approach is adequate, or when there is the need to proceed to a more complex level of analysis (Burrough, 1996). Therefore, in developing countries where inadequate land resources data exist and where funds are limiting to carry out detailed data analysis, qualitative physical land evaluation methodology may be used, which may later be complemented with quantitative methods.

The objective of the study is to use a qualitative method of assessment to evaluate a landscape with inadequate land resources data for specified land utilization type. This approach is aimed at identifying areas of the landscape that are suitable for intended land utilization type, which can then be further subjected to detailed investigation using quantitative methods.

\section{Materials and methods}

The surveyed area $(1,760 \mathrm{ha})$ lies between latitude $11^{\circ} 20^{\prime} \mathrm{N}$ and $11^{\circ} 18^{\prime} \mathrm{N}$ and longitudes $4^{\circ} 03^{\prime} \mathrm{E}$ and $4^{\circ} 05^{\prime} \mathrm{E}$ at approximately $300 \mathrm{~m}$ above sea level on a gently sloppy upland (Fig. 1). The climate is tropical lowland warm-subhumid with distinct seasons. There is a wet season from May to October, harmattan season from November to January and a hot dry season from February to mid-May. The total annual rainfall ranges from $750 \mathrm{~mm}$ to $1016 \mathrm{~mm}$, with a mean of $968 \mathrm{~mm}$ which is characterized by one peak-wet season. The mean annual temperature is $32{ }^{\circ} \mathrm{C}$. There is a rainfedgrowing period of about 140 days in most years. The area is underlain by cretaceous sediment which consists of false-bedded, medium to coarse-grained grit studded with quartz stones and pebbles.

\section{Land use}

Agricultural development is very low. The native vegetation is still minimally disturbed, although, annual bush burning is rampant. The dominant pastoral activities are cattle and sheep grazing. Grazing by cattle(kept by indigenous Fulani nomads) is not systematic and is not controlled. Cropping activities are extensive with cereal crops, sorghum and millet being the major crops. Cropping system is mixed, with groundnut planted between rows of sorghum and/or millet.

\section{Data set}

The data set consists of primarily 100 


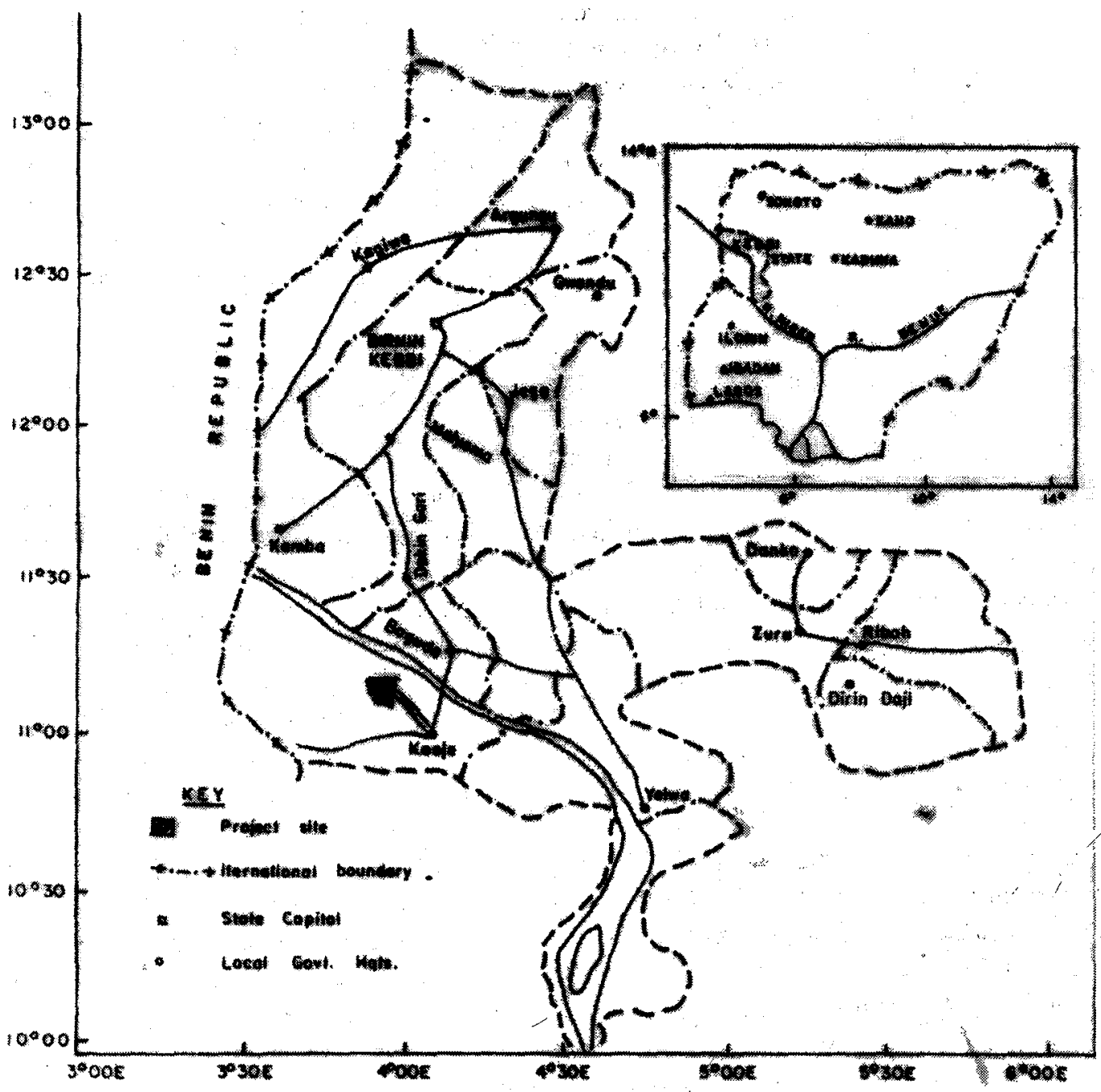

Fig. 1. Location map of the study site

sampling sites arranged on a systematic, equilateral grid with approximately $1.5 \mathrm{~km}$ spacing between sites. The sites were confined within the Yelwa 1:50,000 topographic map sheet. At each site, vegetation and soil attributes were recorded according to the methods described by Oluwatosin et al. (2002). The landscape was divided into upland (crest/upper/ midslope), plains and valley bottom. The upland (crest/upper/midslope) soils were classified as Kandiustults, those derived from the plains as Hapluaquent, and those formed in the valley bottom as Kandiaquult (Oluwatosin et al., 2002).

\section{Land characteristics and their rating}

Land characteristics (LC) are simple attributes of the land that can be directly measured or estimated in routine surveys, 
including remote sensing as well as resource survey (Rossiter, 1996; FAO, 1976; Dent \& Young, 1981). Land characteristics that are important in this zone are shown in Table 1. The land characteristics were standardized to the common scale $(0 \ldots .4)$ following the modified Sys et al. (1991) standardized tables 2 and 3. Land quality indices are derived from a set of standardized continuous LC values, which are then combined with weighting factors to arrive at a land quality rating. Thus, the ' $n$ ' land characteristics $(\mathrm{LC})_{\mathrm{LEU}}$ are aggregated into ' $m$ ' land qualities (LQ) LEU.LUT $_{\text {specific to }}$ the land utilization type (LUT), before computing a final suitability. Thus, land quality is a function of land characteristics:

$$
\begin{aligned}
& \mathrm{S}_{\text {LEU.LUT }}=f 1_{\text {LUT }}\left(\{L C\}_{\text {LEU.LUT }}\right) \ldots \ldots \ldots \ldots \ldots 1 \\
& L_{\text {LEU.LUT }}=f 2_{\text {(LUT.LUR) }}\left(\{L C\}_{\text {LeU.LUR }}\right) . V L Q \\
& \epsilon\{\mathrm{LUR})_{\mathrm{LUT}} \ldots \ldots \ldots \ldots \ldots \ldots \ldots \ldots \ldots . .2
\end{aligned}
$$

where $\{L U R\}_{\text {LUT }}$ is the set of land-use requirements defined for the LUT and, for each of these, the value of corresponding land quality (LQ) is calculated.

$\{L C\}_{\text {(LEU.LUR) }}$ shows the set of diagnostic LCs used in evaluating land quality. Thus, each land quality is evaluated from a set of diagnostic LCs (Tables 2 and 3 ). (LUT.LUR) means that land-use requirements (LUR) are defined within the context of a specific production system LUT. LEU is the land evaluation unit, and LQ is land quality.

\section{Land qualities and their rating}

Land qualities (LQ) are the complex attributes of land that act in a manner distinct from the actions of other land qualities in their influence on the suitability of land for a specified kind of use (FAO, 1983). It is the ability of the land to fulfill specific requirements for a LUT (Rossiter, 1996). Usually they cannot be measured directly. Instead several measurable diagnostic land characteristics that directly influence the chosen land qualities are used. In this study, seven relevant land quality groups were considered (Table 1). These are moisture availability $(\mathrm{m})$, nutrient availability (f), oxygen availability (o), nutrient retention (n), land workability (s), erosion hazard (e) and climate (c).

Climate. For agricultural land evaluation, climate determines the suitability of a given crop because it influences all components of a farming system (Zhang, 1989). This factor was assessed for the whole area because of its importance on the agricultural potential of regions. This quality was measured by the length of the growing season, solar radiation, temperature and relative humidity because these variables are fundamental to growth, development and harvest quality of the crops considered. However, in this region climatic restriction does not profoundly prevent the growth of cereals and grain legumes. Nevertheless, these variables are rated but not used as differentiating characteristics.

Moisture availability. This land quality was assessed for the whole area but was not used as differentiating property for the mapping units. Crops were affected by moisture availability through the effects of moisture stress on growth. Rainfall during the growing season was used to rate moisture availability because it was more reliable than other measures (Oluwatosin \& Ogunkunle, 1991).

Nutrient availability. This was estimated in a composite of 30 samples 
. S00Z'L'101 'K8ojosg

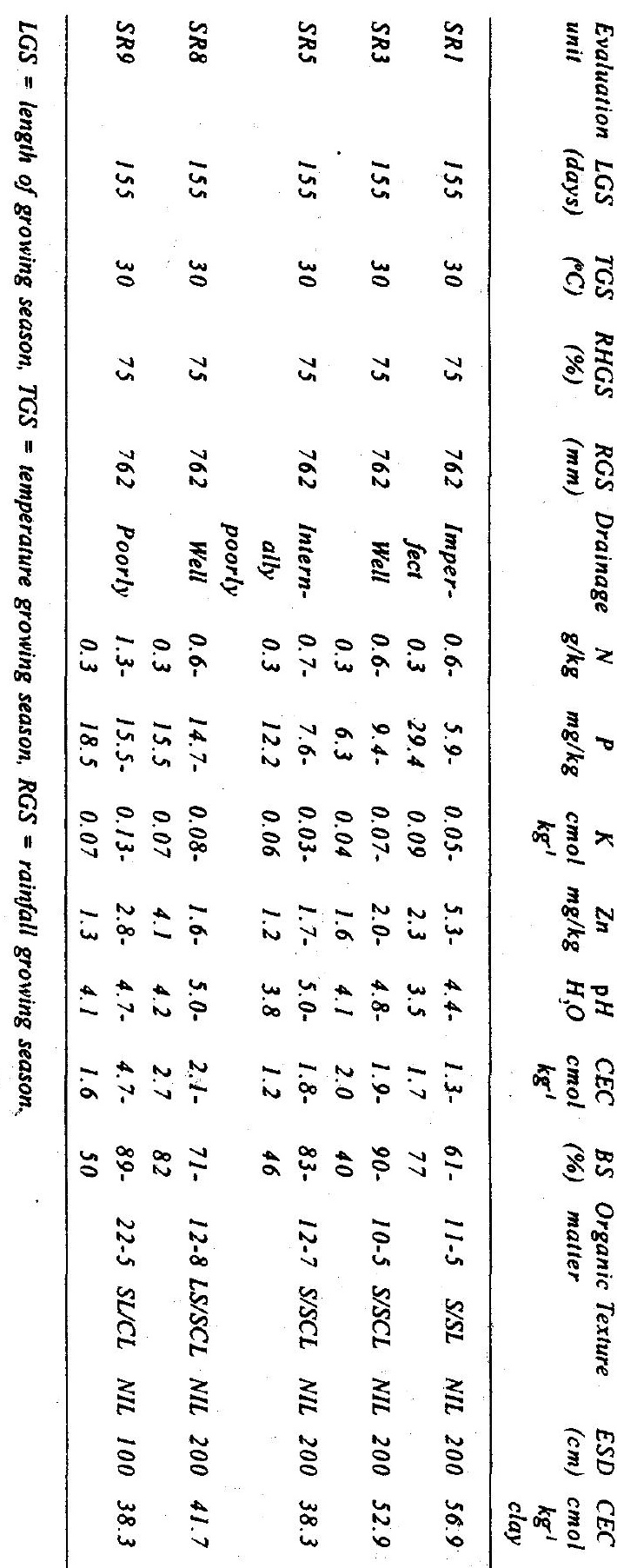




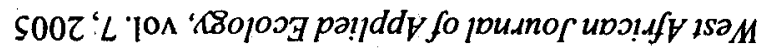
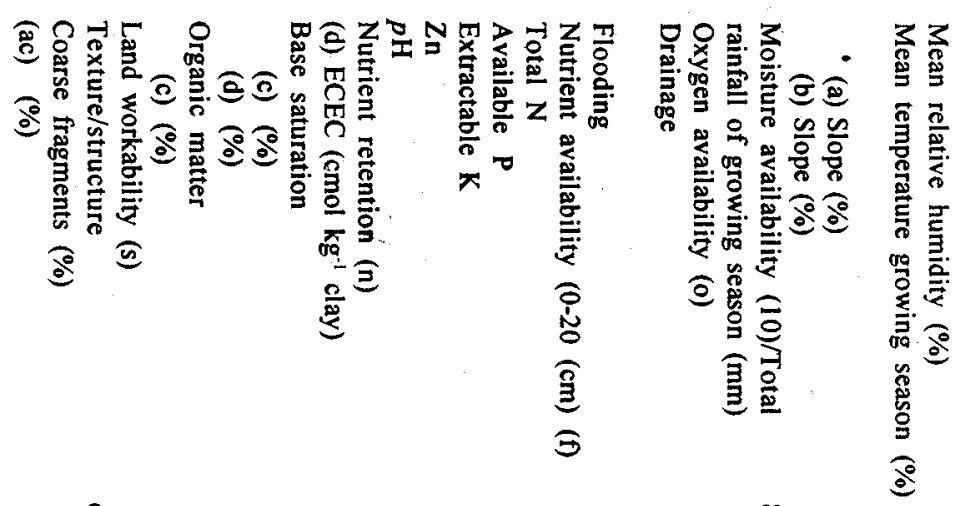

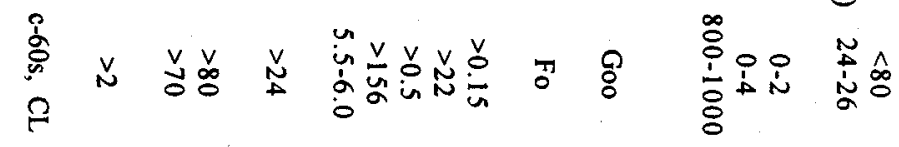

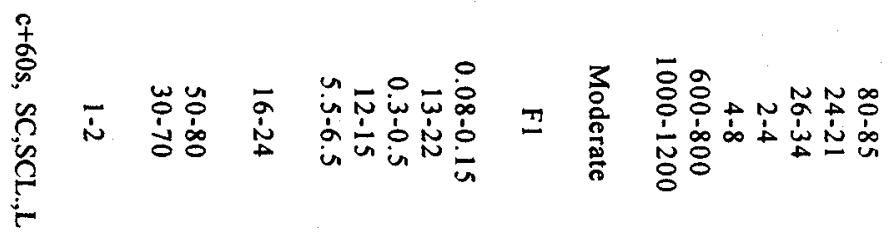

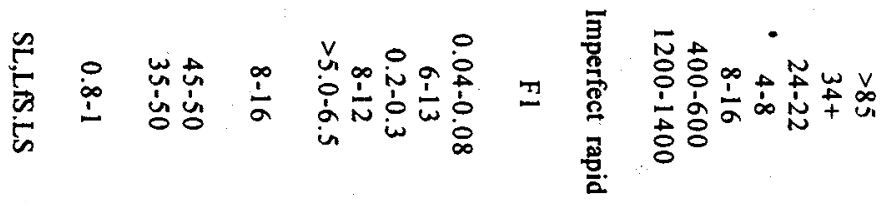

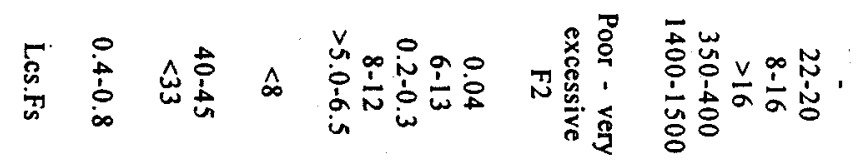

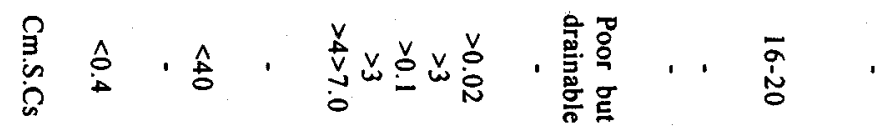




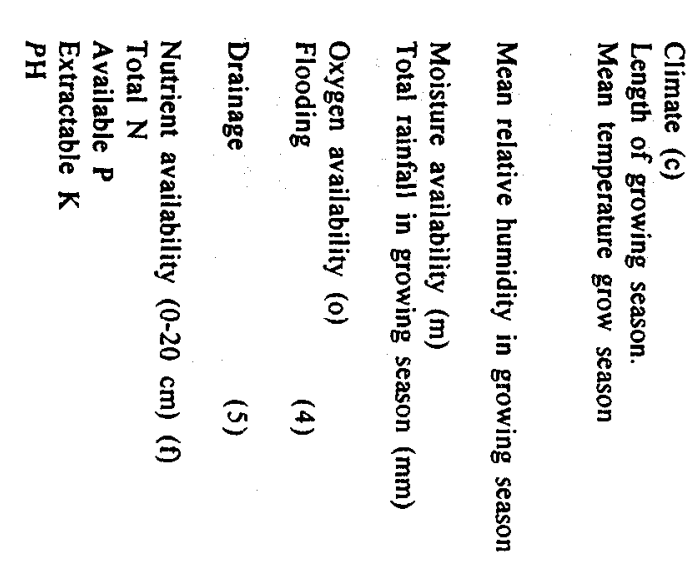

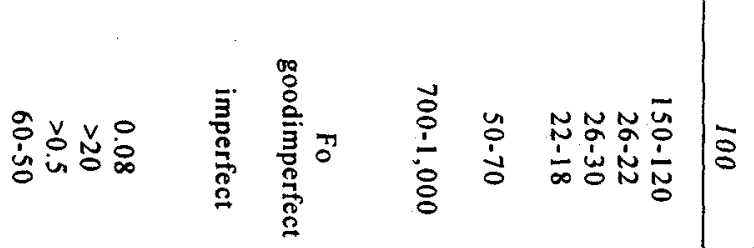

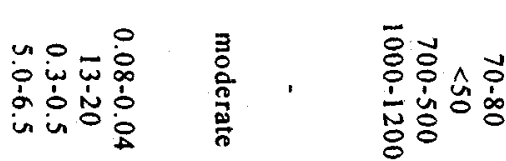

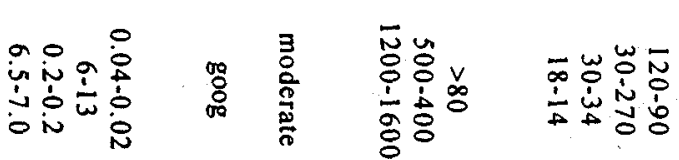

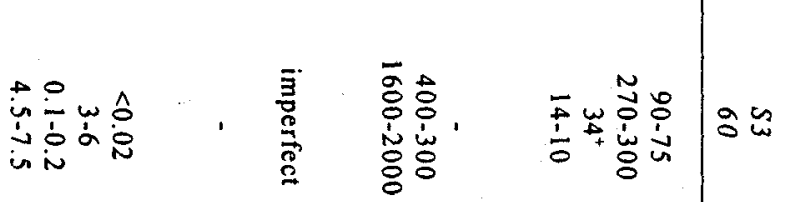

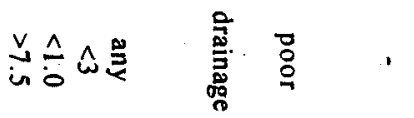


S00Z ' L '

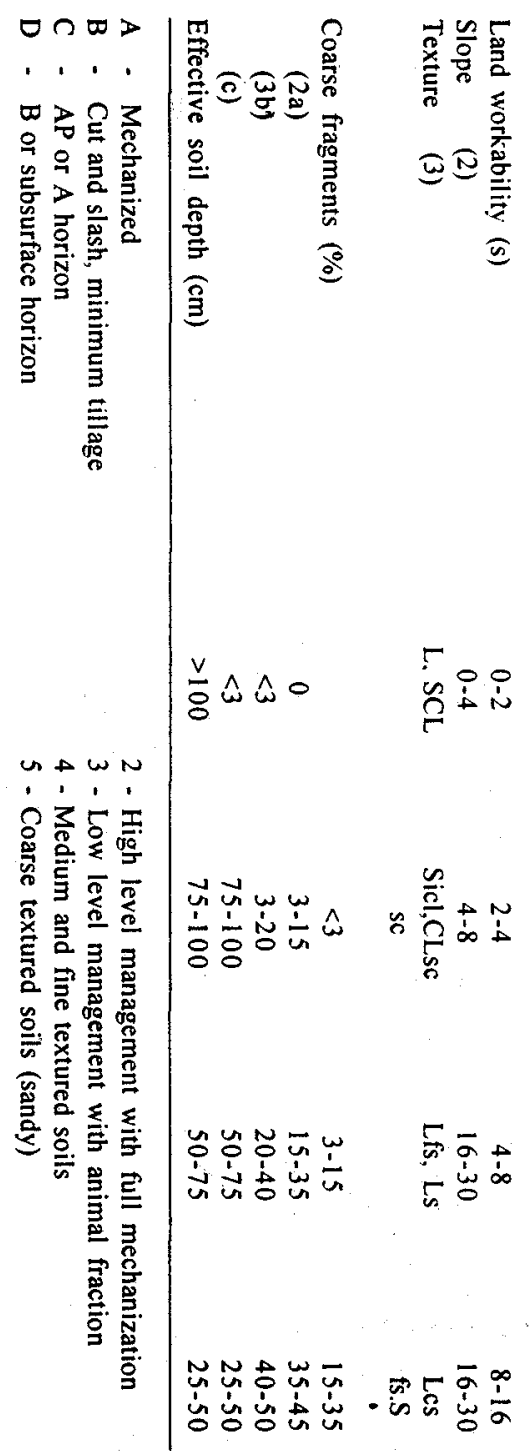


taken from the top $20 \mathrm{~cm}$ of each evaluation unit(Oluwatosin etal.,2002). The rating of measured major nutrients (NPK, Zn) and $p \mathrm{H}$ was developed from the experience of agronomists in Nigeria (FMANR, 1990). The overall rating of nutrient availability was calculated by summing up all the subratings.

Nutrient retention. This land quality was estimated from cation exchange capacity (CEC), base saturation and organic carbon content. The CEC ( $\mathrm{cmol} \mathrm{kg}^{-1}$ clay) and base saturation of the subsoil were used (Oluwatosin et al., 2002). CEC ( $\mathrm{cmol} \mathrm{kg}^{-1}$ ) of the topsoil was not recommended for this purpose (Sys, 1985) because organic matter which also substantially contributed to CEC was strongly affected by management. All the soils have more than one B sub-horizon, therefore, the weighted average was used. Base saturation was used as an index of leaching intensity. Tables 2 and 3 show the sub-rating of the characteristics. The land quality rating itself was calculated by summing up all the sub-rating.

Oxygen availability to the root zone. This land quality was determined primarily by the drainage condition and soil structure. It was assumed that the drainage classes based on hydromorphic features observed in any soil profile, as proposed by the Working Group on Land Evaluation (1975), reflect oxygen supply to the roots.

Land workability. This land quality was observed from slope, effective soil depth to rock coarse fragment, gravelly subsoil and texture. Slope has a much greater influence on land workability than the other characteristics. To reflect this in the rating, slope was rated under most important characteristics while others were rated under less important characteristics (Table 4).
Effective soil depth and coarse fragments influence the ease with which land can be cultivated mechanically. The land quality was rated from the sum of the sub-rating.

Water (inter-rill) erosion hazard. The procedure applied in this study assumed both high and low input farming system and consisted of estimating detachability, transport capacity and expected soil loss. The rating of erosion hazard depends on the soil loss tolerated, and this depends on the effective soil depth and importance of the A-horizon with respect to the fertility of the soil. A deep soil with very fertile topsoil, as reflected by a high CEC/clay ratio, has a larger soil loss tolerance than a deep soil with low CEC/clay ratio or a shallow soil with a high CEC/clay ratio. Veldkamp (1987) developed ratings for erosion hazard which were applied in this study (Table 5).

\section{Land suitability evaluation system}

Six land utilization types (LUTs) are considered here, namely maize, sorghum, millet, groundnut, soybean and cowpea. Suitability for a particular land utilization type is determined by matching crop requirements (LURs) with site characteristics (LQs). The minimum crop requirements (Table 6 ) are based on information in the literature, expert opinion and on comparison of measured values of characteristics with expert judgement on limitations to land utilization types (Koppi, 1991). The soil suitability component of this system recognizes the potential of a given area for a specific land utilization by interpreting routinely measured soil variables that are available in the database of the area (Oluwatosin et al., 2002).

To assess a particular evaluation unit, a parametric modeling of the relevant soil 
Rating of limiting characteristics

\begin{tabular}{clcc}
\hline Rating Symbol & Intensity of limitation & $\begin{array}{c}\text { Most important } \\
\text { characteristics }\end{array}$ & $\begin{array}{c}\text { Less important } \\
\text { characteristics }\end{array}$ \\
\hline 0 & No & $95-100$ & $95-100$ \\
1 & Slight & $85-95$ & $90-95$ \\
2 & Moderate & $60-85$ & $85-90$ \\
3 & Severe & $25-60$ & $60-85$ \\
4 & Very severe & $<25$ & $<60$ \\
$(1)$ & Can be corrected & $20-25$ & $50-60$ \\
$(2)$ & Can not be corrected & $<2$ & $<50$ \\
\hline
\end{tabular}

TABle 5

Rating of water (inter-rill) erosion hazard

Expected soil loss (t/ha/yr) for soil depth (cm)

$>90 \quad 60-90 \quad 30-60<30$

Rating

(a) Cation exchange capacity (clay) over $0-50 \mathrm{~cm}>30 \mathrm{cmol} \mathrm{kg}^{-1}$

$\begin{array}{cccclc}0-10 & 0-7 & 0-4 & 0-2 & 1 \text { (none slight) } & \text { none } \\ 11-25 & 8-18 & 5-11 & 3-4 & 2 \text { (low) } \\ 26-60 & 19-43 & 12-26 & 5-9 & 3 \text { (moderate) } \\ >60 & >43 & >26 & >9 & 4 \text { (high) }\end{array}$

(b) Cation exchange capacity (clay) over $0-50 \mathrm{~cm} 15-30 \mathrm{cmol} \mathrm{kg}^{-1}$

$\begin{array}{cccclc}0-6 & 0-4 & 0-2 & 0-1 & 1 \text { (none or slight) } & \text { SRI, } 5,8 \\ 7-15 & 5-11 & 3-7 & 2 & 2 \text { (low) } \\ 15-36 & 11-26 & 8-16 & 3-4 & 3 \text { (moderate) } \\ >36 & >26 & >16 & >4 & 4 \text { (high) }\end{array}$

(c) Cation exchange capacity (clay) over $0-50 \mathrm{~cm}<15 \mathrm{cmol} \mathrm{kg}^{-1}$

$\begin{array}{cccclc}0-3 & 0-2 & 0-1 & 0 & 1 \text { (none or slight) } & \text { SRI, 3,9 } \\ 4-8 & 3-5 & 2-3 & 0 & 2 \text { (low) } & \\ 9-18 & 6-13 & 4-8 & 1 & 3 \text { (moderate) } \\ >18 & <13 & <8 & >1 & (4 \text { (high) }\end{array}$

characteristics/qualities for each crop(LUT) was used to estimate the overall limitation effect. Each land characteristic under each land quality was sub-rated to arrive at the final rating for each land quality (Table 7).
The aggregate suitability rating was obtained by rating all the land qualities considered (Sys, 1991). As an example, the overall suitability rating for maize under evaluation unit SR 1 is calculated as: 
$\mathrm{S}_{\text {LEu LUt }} \underset{\text { (f) }}{=15} \times \frac{85}{100} \times \frac{85}{100} \times \frac{90}{100} \times \frac{95}{100} \times \frac{100}{100} \times \frac{100}{100}=9$

(c) $\quad(m) \quad(0) \quad$ (n) $\quad$ (s) $\quad$ (e)

$S_{(1) L E U L U T}=85 \times \frac{85}{100} \times \frac{85}{100} \times \frac{90}{100} \times \frac{95}{100} \times \frac{100}{100} \times \frac{100}{100}=53$

where $S_{\text {LEU LUT }}=$ actual (current) index of suitability (i.e. when land quality fis included in the rating because low fertility management is envisaged); $S_{(t) L e U ~ u r r}=$ potential index of suitability (i.e. when quality $f$ is not included because high fertility management is envisaged).

Suitability classes $\mathrm{S} 1, \mathrm{~S} 2, \mathrm{~S} 3$ and $\mathrm{N}$ are equivalent to Index of suitability values of $100-75,74-50,49-25$ and $24-0$, respectively

TABLE 6

Minimum requirements of the land utilization types for optimum productivity

\begin{tabular}{lcccccc}
\hline $\begin{array}{l}\text { Land } \\
\text { utilization } \\
\text { type }\end{array}$ & $\begin{array}{c}\text { Moisture } \\
\text { availability }\end{array}$ & $\begin{array}{c}\text { Nutrient } \\
\text { retention }\end{array}$ & $\begin{array}{c}\text { Nutrient } \\
\text { availability }\end{array}$ & $\begin{array}{c}\text { Oxygen } \\
\text { availability }\end{array}$ & $\begin{array}{c}\text { Land } \\
\text { workability }\end{array}$ & $\begin{array}{c}\text { Wate } \\
\text { erosion } \\
\text { hazard }\end{array}$ \\
\hline Maize & 3 & 2 & 2 & 2 & 3 & 2 \\
Sorghum & 3 & 2 & 2 & 2 & 3 & 2 \\
Millet & 3 & 2 & 2 & 2 & 3 & 2 \\
Groundnut & 3 & 3 & 3 & 2 & 2 & 3 \\
Soybean & 3 & 3 & 3 & 2 & 3 & 2 \\
Cowpea & 3 & 3 & 3 & 2 & 2 & 2 \\
\hline
\end{tabular}

$2=\leq 25 \%$ reduction in optimum yield

$3=\leq 40 \%$ reduction in optimum yield

TABLE 7

Summary of the land quality ratings of the mapping units using intensity of limitations

\begin{tabular}{lccccccc}
$\begin{array}{l}\text { Land } \\
\text { unit }\end{array}$ & $\begin{array}{c}\text { Moisture } \\
\text { availability } \\
(m)\end{array}$ & $\begin{array}{c}\text { Nutrient } \\
\text { availability } \\
(f)\end{array}$ & $\begin{array}{c}\text { Nutrient } \\
\text { retention } \\
(\boldsymbol{n})\end{array}$ & $\begin{array}{c}\text { Oxygen } \\
\text { availability } \\
(0)\end{array}$ & $\begin{array}{c}\text { Land } \\
\text { workability } \\
(\mathrm{s})\end{array}$ & $\begin{array}{c}\text { Water erosion Climate } \\
\text { hazard } \\
(\mathrm{e})\end{array}$ & (c) \\
\hline SR1 & 1 & 3 & 1 & 2 & 1 & 0 & 0 \\
SR3 & 1 & 3 & 1 & 0 & 1 & 2 & 0 \\
SR5 & 1 & 3 & 1 & 2 & 1 & 0 & 0 \\
SR8 & 1 & 3 & 1 & 0 & 1 & 2 & 0 \\
SR9 & 1 & 3 & 1 & 2 & 2 & 0 & 0 \\
\hline
\end{tabular}

$0=$ no limitation: characteristic is optimal for plant growth

1 = slight limitation: characteristic is nearly optimal for plant growth and affects productivity for not more than $20 \%$

2 = moderate limitation: characteristic has moderate influence on yield decrease for sustained use; benefit can still be made and use of land remains profitable

3 = severe limitation: a characteristic has such an influence on yield decrease or degradation of the land that the use becomes marginal for considered land utilization type 
(Sys, 1985).

\section{Result and discussions}

The soils

All the soils are deep and well developed as evidence by the presence of textural $B$ (Argillic/Kandic) horizons with low base saturation ( $\mathrm{BS} \leq 35 \%$ ), which are diagnostic of the Ultisols. The upland soils are well drained while those of the plain and valley bottom show some degree of poor drainage (aquic moisture regime). The texture of the soil ranges between loamy sand/sand (top) and sandy clay loam/clay loam(sub-horizon). The upland soils are Ultisols (Lixisols) while those of the plain and valley bottom are Inceptisols (Gleysols) (Oluwatosin et al., 2002). The soils are acidic, very low in cation exchange capacity, organic matter, nitrogen and phosphorus (Table 1). Therefore, management of organic matter for nutrient retention and for better aggregation to reduce susceptibility to runoff and erosion is required for sustainable crop production.
Suitability classes

Table 6 shows the minimum requirements of the crops considered, while Table 7 shows the individual ratings for the evaluation units. The aggregate rating is for both current (actual) suitability (when all relevant qualities were considered) and potential suitability (when land quality ' $f$ ' is excluded in view of its transient nature). The classification is summarized in Table 8 . The result shows that all evaluation units are currently not suitable (N1) with the index of suitability ranging between 10 and 18 for cereal crops under the present farming system. However, they are marginally suitable (S3,47-56) for grain leguminous crops considered. This is because all the units did not meet the minimum requirements for the cereal crops but meet those for leguminous crops for optimum productivity (Table 6).

Potentially, all the evaluation units are moderately suitable (S2, 61-69) for cereal. crops. The suitability for grain legumes, however, ranges between highly suitable (S1, 82-88) and marginally suitable (S3, 4956). All the three cereal crops fall into the

TABLE 8

Land suitability of different mapping units to selected land utilization types

\begin{tabular}{llllllll}
\hline Land unit & \multicolumn{1}{c}{ Level } & Maize & Sorghum & Millet & Groundnut & Soybean & Cowpea \\
\hline SR1 & Actual & N1fo(9) & N1fo(11) & N1fo(16) & S3fo(51) & S3fo(52) & S3fo(50) \\
& Potential & S2o(53) & S2o(66) & S2o(69) & S1(85) & S1(88) & S2o(67) \\
SR3 & Actual & N1fe(12) & N1fe(15) & N1fe(13) & S3f(56) & S3f(56) & S3f(49) \\
& Potential & S2e(69) & S2e(66) & S2e(66) & S2f(73) & S2f(74) & S2f(72) \\
SR5 & Actual & N1fo(13 & N1fo(11) & N1fo(12) & S3fo(56) & S3fo(47) & S3fo(53) \\
& Potential & S2o(56) & S2o(63) & S2o(63) & S1(82) & S1(88) & S2o(73) \\
SR8 & Actual & N1fe(13) & N1fe(11) & N1fe(13) & S3f(56) & S3f(51) & S3f(55) \\
& Potential & S2e(69) & S2e(63) & S2e(64) & S2f(76) & S2f(66) & S2f(67) \\
SR9 & Actual & N1fo(18) & N1fo(14) & N1fo(11) & S3fo(53) & S3fo(49) & S3fo(49) \\
& Potential & S2o(61) & S2o(64) & S2o(65) & S3o(53) & S2o(72) & S3fo(51) \\
\hline
\end{tabular}

$\mathrm{S} 1=$ highly suitable; $\mathrm{S} 2=$ moderately suitable; $\mathrm{S3}=$ marginally suitable; $\mathrm{N} 1=$ currently (actual) not suitable

$\mathrm{f}=$ nutrient availability; $\mathrm{e}=$ erosion hazard $\mathrm{o}=$ oxygen availability; $s=$ workability. 
same suitability class (S2). This is because they have the same minimum requirements for optimum productivity. However, the evaluating units have different suitability classes for the legume crops. For example, unit SR5 SR5 (Plains) was in the highly suitable(S1,81-88) class for groundnut and soybean but moderately suitable (S2, 6773) for cowpea. The difference is the minimum requirements for oxygen availability (Table 6) that is required for optimum productivity. Similarly, while soils on plains are potentially highly suitable ( $\mathrm{S} 1$, 82-85) for groundnut, those on upland are moderately suitable (S2,73-76) and valley bottom marginally suitable (S3,53). Again, the differences are the intensity of the limitations, in this case, oxygen availability (o).

The evaluating units on the plains seem potentially most suitable for both cereals and grain legume crops. However, grain legumes are potentially the most suitable crops in all the evaluation units. This is because all the evaluation units meet their minimum requirements for land quality ' $f$ '. Nevertheless, the low level of phosphorus and the low $p \mathrm{H}$ coupled with the morphological properties that tend to favour P fixation (Buol \& Denton, 1984) might be responsible for the marginality of the landscape for leguminous crops under the current suitability. Therefore, the addition of booster dose of phosphorus fertilizer is needed to obtain optimum yield of legumes in these soils.

\section{Major limitation to suitability}

Table 8 shows that climate (c), moisture availability $(\mathrm{m})$ and nutrient retention $(\mathrm{n})$ are optimal or nearly so for the land utilization types considered. On the other hand, nutrient availability (f) is sub- optimal and is, therefore, a major limitation to arable crop production across the landscape under the present farming system. Similarly, erosion hazards (e) was the other limitation in the upland while oxygen availability (o) was the other limitation in the valley bottom and the plain. The result is noteworthy particularly for the West African sub-region that is characterized by landscapes with catenary sequence. Nutrientavailability (f) cuts across all the evaluating units and is, therefore, considered as the most critical of all the land qualities. Ogunkunle (1993) also found that land quality f was the major limitation to the suitability of Nigeria soils to oil palm growth. Similarly, in the Zambia, Chinene (1992) showed that land quality $f$ was one of the two major limitations to arable crop production even under high input level. Nutrient availability is considered a major limitation in this study area because majority of the farmers can not easily amend this limitation due to economic reasons.

The severity of the limitation also depends on the existing farming system (Fresco et $a l ., 1994)$. For example, land quality $f$ is the most limiting quality to crop production in this area, which implies that optimum productivity can be achieved only by high fertility management. The severity of this limitation becomes important because the present farming system (low input) can not offset the limitation. Most of the farmers have no access to capital and other farm inputs such as fertilizer. Even though there is inclusion of leguminous cover crops in the cropping system, little or no nutrients are returned to the soil because the residues from the legumes are fed to livestock. However, the present tillage methods and the cropping systems (cereal/legume 
mixtures) could conveniently cope with and/ or reduce the incidence of erosion by water. Therefore, fertility management is critical to optimum crop production in this area. This may be the reason why the soils are not suitable for cereal crops because of its high fertility demand. On the other hand, land quality e was assumed to be not severe under the present farming system in that both methods of land preparation (minimum tillage and animal traction) and cropping system (cereal/legume mixture) are efficient in checking erosion by water. This evaluation is the qualitative assessment of these soils. It shows that if the limitations identified can be corrected (e.g. by soil management) all the crops can perform better in these soils. However, this result needs to be confirmed quantitatively with actual grain yield.

\section{Conclusion}

The use of qualitative land evaluation based on parametric method that assesses the suitability of land on a continuous scale is feasible in this region of Nigeria where there is lack of detailed data and.fund to carry out comprehensive land resources studies. This method can identify the most limiting land qualities for crop production, and can, thus, be used to advise farmers and other land users on the suitability of their farmland as well as provide appropriate land management practices for sustainable crop production. Soil fertility management (especially, high fertilizer input) is required for optimum crop production in this landscape. The severity of this limitation becomes important because of the nutrient mining nature of the farming system. Furthermore, land evaluation should take into consideration the farming system of the land users in order to arrive at the suitability ratings that will lead to the sustainable use of their land.

Future land evaluation of the area should consider the soil physical properties and water availability to improve predictions of sustainability of the area and land utilization types. The use of dynamic models of crop growth as demonstrated by Katawatin et al. (1996) in their simulation modeling for land suitability evaluation for dry season peanut cropping in northeast Thailand may prove useful.

\section{Reference}

Buol S. W and Denton H. P. (1984), The Role of Soil Classification in Technological Transfer. Soil Sci. Soc. Am. Pap. No.8951. N.C. Agric. Res. Serv. Raleigh.

Beek K. J. (1978). Land evaluation for agricultural development. Inter. Land Res.

Inst. Publ. 23. ILRI, Wageningen.

Burrough P. A. (1996). In J. Bouma: Discussion of paperby D.G. Rossiter. Goederma 72: 191 $-202$.

Chinene U.R. N. (1992). Land evaluation using theFAO framework: an example from Zambia Soil Use Mgmt 8: 130-139.

Dent D and Young A. (1981). Soil survey and land evaluation. George Allen and Unwin, London.

FAO (1976). A framework for land evaluation. Soil Bull. 52. Food and Agricultural Organization, Rome.

FAO (1983). Guidelines: Land evaluation for rainfed agriculture. Soils Bull.54. Food and Agricultural Organization, Rome.

Federal Ministry of Agriculture and Natural Resources (1990). Literature review on soil fertility investigations in Nigeria. FDA, Lagos. $281 \mathrm{pp}$.

Fresco L. O., Huizing H. G., Van Keulen H. and Schipper R. A. (1994). Landevaluation and farming systems analysis for land use planning. FAO Working Document. FAO, 
Rome. 209 pp.

Katawatin R., Crown P. H. and Grant R. F. (1996). Simulation modeling of land suitability evaluation for season peanut cropping based on water availability in northeast Thailand: evaluation of the MACROS crop model Soil Use Mgmt 12:25-32.

Koppi A. J. (1991). Site description, profile morphology and land evaluation. In Soil technology-applied soil science. (S S. Barnnerman and P. Hazelton, ed.) pp 113-137. Australian Soil Science Society Incorporated, New South Wales and University of Sydney, Sydney.

Ogunkunle A. O (1993). Soil in land suitability evaluation: An example with oil palm in Nigeria. Soil Use Mgmt 9: 1.

Oluwatosin G. A. and Ogunkunle A. O. (1991). Suitability ratings of some soils of the savanna zone of southwestern Nigeria for rainfedmaize. Niger. Soil Sci. 10: 1-24.

Oluwatosin G. A., Onileowo O. T. and OjoAtere J. O. (2002). Characterization of soil in the continental grits of northwestern Nigeria.

J. Trop. For. Res. (In press).

Rossiter D. G. (1996). A theoretical framework for land evaluation. Geoderma 72: 165-190. Smit B., Brkacich M., Dumanski J. McDonald K. B. and Miller M. H. (1984). Integral land evaluation and its application to policy. Canadian J. Soil Sci. 64: 467-479.

Storie R. E. (1933). An index for rating the agricultural value of soils (rsed 1937). University of California Agricultural Experimental Station Bulletin 556. Berkley, California.

Sys C. (1985). Land evaluation, parts 1- 4. International Training Centre for Postgraduate Soil Scientists. State University of Ghent, Ghent.
Sys C, Van Ranst E. and Debaveye J. (1991).

Land evaluation, part II: Methods in land evaluation Agricultural publication No. 7 , General Administration for Development Cooperation, Brussels. 247 pp.

Van Diepen C. A., Van Keulen H., Wolf J. and Berkhout J. A. A. (1991). Land evaluation from intuition to quantification. In Advances in Soil Science (B. A. Stewart, ed. ), pp. 139204. Springer-Verlag, New York.

Van Lanen H. A. J. (1991). Qualitative and quantitative physical land evaluation: an operational approach. (PhD Thesis.), Agricultural University, Wageningen. 195 pp.

Van Ranst E., Tang H., Groenemans R. and Sinthurahat S. (1996). Application for fuzzy logic to land suitability for rubber production in peninsular Thailand. Geoderma 70: 1-19.

VeldKamp W.J(1987). Reconnaissance/semidetailed land evaluation system for rainfed agriculture, $1^{\text {st }}$ edn. Technical Guide No. 19. Soil Survey Unit, Research Branch, Department of Agriculture, Lusaka.

Verheye W.H.(1986). Principles of land appraisal and land use planning within the European Community. Soil Use Mgmt 2: 120-124.

Working Group On Land Evaluation (1975). Some land utilisation types in Surinam. Criteria for land suitability classification. DBK Report 52, Department of Soil Survey, Paramaribo.

Yizengaw T. and Verheye W. (1995). Application of computer captured knowledge in land evaluation using ALES in Central Ethiopia. Geoderma 66:297-231.

Zhang L. A. (1989). A land suitabilityevaluation for specific rural purposes in New South Wales. (Ph. D thesis.) The University of Sidney, NSW, Australia. 